\title{
Accelerated Shelf-life Testing to Predict Quality Loss in Romaine-type Lettuce
}

\author{
Catherine E. Belisle ${ }^{1}$, Steven A. Sargent ${ }^{1}$, Jeffrey K. Brecht ${ }^{1}$, \\ Germán V. Sandoya ${ }^{2}$, and Charles A. Sims ${ }^{3}$
}

\begin{abstract}
ADDITIONAL INDEX wORDs. Lactuca sativa, postharvest, Q10
SUMMARY. The postharvest life of lettuce (Lactuca sativa) is variable and negatively affected by mechanical injury, incomplete cooling, and poor genetic quality. Lettuce breeders are developing cultivars with a longer shelf life and rely on subjective, destructive, and time-consuming methods for quality analysis. One method of accelerating quality evaluations is known as accelerated shelf-life testing (ASLT), which has the potential to assist breeders in assessing lettuce quality and shelf life. The objective of this research was to determine the quality traits that significantly affect shelf life to develop an ASLT procedure to rapidly assess the postharvest quality of lettuce accessions in breeding programs. In Test 1, Romaine lettuce quality was evaluated using one subjective and five objective parameters during storage at $5,10,15$, or $20^{\circ} \mathrm{C}$. Results determined that weight loss, lightness*, and hue* angle were best correlated with the overall appearance rating, whereas storage at 10 or $15^{\circ} \mathrm{C}$ differentiated the shelf-life potential quickly and without excessive deterioration. In Test 2 , these objective characteristics and storage temperatures were used to study rates of quality deterioration of a commercial Romaine cultivar (Okeechobee) and a breeding line (60182), both with long shelf lives, and a Batavia lettuce cultivar (La Brillante) with a short shelf life. Lettuce was evaluated during storage at $10^{\circ} \mathrm{C}$ (winter and spring seasons) or at $15^{\circ} \mathrm{C}$ (winter season). Weight loss was the most appropriate quality index for lettuce at these storage temperatures for a single harvest, whereas lightness* and hue* angle were the most appropriate indices for comparing quality between harvests. To apply ASLT to postharvest assessments of lettuce, breeders and other researchers should include two controls with good and poor shelf life (similar to 'Okeechobee' and 'La Brillante', respectively) as standard baseline cultivars during storage at either 10 or $15^{\circ} \mathrm{C}$.
\end{abstract}

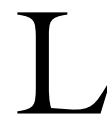

ettuce (Lactuca sativa) has an annual production value of $\$ 3.5$ billion in the United States (U.S. Department of Agriculture, 2020 ), with $\approx 24.7$ lb of lettuce consumed per capita (U.S. Department of Agriculture, 2019). The crop is highly perishable, with an estimated shelf life of 2 to 3 weeks when kept under the recommended storage conditions slightly above $0{ }^{\circ} \mathrm{C}$ and $98 \%$ to $100 \%$ relative humidity $(\mathrm{RH})$ (Saltveit, 2016). Lettuce shelf life can be assessed subjectively using visual quality evaluations (Kader et al., 1973; Simko and Hayes, 2018) and objectively by measuring features such as water loss, color changes, texture, and other physiological and chemical evaluations. To assess visual quality of lettuce, Kader et al. (1973) developed widely used 5- to 9-point scales with descriptors for firmness, visual quality, decay, discoloration, wilting, and unspecified defects. With a well-defined lexicon, visual evaluations proved to be accurate and reliable for discriminating lettuce shelf life over a range of storage temperatures (Bolin et al., 1977) and for experienced and inexperienced sensory panelists (Simko and Hayes, 2018).

Objective evaluations reduce the variability that is inherently present with subjective evaluations, but objective evaluations are time-intensive. For instance, water loss, expressed as a percentage over time, is sensitive to internal and environmental factors that lead to wilting, shriveling, loss of turgidity, and decreased nutritional content (Kader, 2002). Color changes in lettuce are a useful tool for assessing quality and are typically observed as a loss of leaf blade green color because of decreased chlorophyll content, resulting in yellowing and having a significant impact on consumer acceptance (Agüero et al., 2008). Texture analysis of midribs, measured as the force to rupture tissues, indicates a loss of turgidity, which is related to perceived freshness, a characteristic assessed using sensory panels (Ansorena et al., 2009; Martín-Diana et al., 2006) or instrumental measurements (Martín-Diana et al., 2006). Instrumental measurements of the texture of midrib crispness are difficult and less commonly used because of the variability of textures within lettuce tissues (Toole et al., 2000).

Although subjective and objective measurements are ideal for a comprehensive understanding of quality and physiological deterioration as a function of time, they are not practical for breeding programs and commercial cultivar trials during which numerous accessions must be evaluated simultaneously. Typically, breeders evaluate lettuce quality visually, but a fast method of assessing the shelf-life potential is lacking. For example, Simko and Hayes (2018) recommended evaluating shelf life after 42 $\mathrm{d}$ of storage at $3.5^{\circ} \mathrm{C}$. The use of molecular markers is a complicated method of determining shelf life because this trait is controlled by many regions in the lettuce genome (Hayes and Liu, 2008; Kandel et al., 2020).

With a focus on physiology, Achour (2006) compared the aforementioned classical methods of shelflife analysis to those of accelerated shelf-life testing (ASLT), which was first modeled by Labuza and Schmidl (1985). ASLT is used to accelerate the biochemical changes analogous with shelf life and compares the variations of selected quality indices during storage to a numerical or descriptive threshold (Kader et al., 1973; Simko and Hayes, 2018) defined before the experiment by the researchers or

\begin{tabular}{llll}
\hline $\begin{array}{l}\text { Units } \\
\text { To convert U.S. to SI, } \\
\text { multiply by }\end{array}$ & U.S. unit & SI unit & $\begin{array}{l}\text { To convert SI to U.S., } \\
\text { multiply by }\end{array}$ \\
\hline 2.54 & inch(es) & $\mathrm{cm}$ & 0.3937 \\
25.4 & inch(es) & $\mathrm{mm}$ & 0.0394 \\
0.4536 & lb & $\mathrm{kg}$ & 2.2046 \\
4.4482 & $\mathrm{lbf}$ & $\mathrm{N}$ & 0.2248 \\
1 & $\mathrm{ppm}$ & $\mathrm{mg} \cdot \mathrm{L}^{-1}$ & 1 \\
0.9464 & $\mathrm{qt}$ & $\mathrm{L}$ & 1.0567 \\
$\left({ }^{\circ} \mathrm{F}-32\right) \div 1.8$ & ${ }^{\circ} \mathrm{F}$ & ${ }^{\circ} \mathrm{C}$ & $\left({ }^{\circ} \mathrm{C} \times 1.8\right)+32$
\end{tabular}


through the use of official grade standards (Labuza and Schmidl, 1985). During storage, each quality index is rated for degradation, with emphasis given to the quality indices that most quickly violate a pre-set threshold value. These quality indices can include discoloration, phenolics, and antioxidant activity for apple (Malus domestica) and quince (Cydonia oblonga) leathers (Torres et al., 2015), or peroxide values and free fatty acids in walnuts [Juglans regia (Wang et al., 2006)], or yellowing, wilting, and loss of crispness in fresh-cut Romaine lettuce (Manolopoulou et al., 2010). For subjective ratings, numerical or descriptive thresholds are set, typically using hedonic scales with ratings from 1 (extremely poor quality) to 9 (excellent quality) (Kader et al., 1973). A lettuce head is considered "good" or "marketable" at an overall rating of 7 when there are no more than minor defects present on exposed leaves, whereas a rating below the threshold of "fair" (overall rating of 5) has slight to moderate defects and a lower limit of marketability (Kader et al., 1973). These descriptors concur with the description of high-quality lettuce as being clean, crisp, turgid, free of brow-

Received for publication 27 Jan. 2021. Accepted for publication 3 May 2021.

Published online 23 June 2021.

${ }^{1}$ Horticultural Sciences Department, University of Florida/Institute of Food and Agricultural Sciences (IFAS), Gainesville, FL 32611

${ }^{2}$ Horticultural Sciences Department, Everglades Research and Education Center, University of Florida/IFAS, Belle Glade, FL 33430

${ }^{3}$ Food Science and Human Nutrition Department, University of Florida/IFAS, Gainesville, FL 32611

This research was partially funded through a subrecipient grant awarded by the U.S. Department of Agriculture, Agricultural Marketing Service through the Florida Department of Agriculture and Consumer Services (Award No. 266097) and the Hatch projects FLA-EREC-005599 and FLA-HOS-005972. The contents do not necessarily reflect the views or policies of the USDA, nor does the mention of trade names, commercial productions, services, or organization imply endorsement by the U.S. Government.

We thank the Horticultural Sciences Department at the University of Florida for funding provided to C. Belisle and the Florida Vegetable Exchange for assistance with this project. We thank Gustavo Kreutz, William Wadlington, Jesse Murray, Lis Natali Rodrigues Porto, Amanda Carroll, and Heriberto Trevino for help with planting, harvesting, and cooling, and Adrian Berry for assistance with experimental planning and setup.

G.V.S. is the corresponding author. E-mail: gsandoyamiranda@ufl.edu.

This is an open access article distributed under the CC BY-NC-ND license (https://creativecommons. org/licenses/by-nc-nd/4.0/).

https://doi.org/10.21273/HORTTECH04812-21 ning, and having bright, light green leaves (Saltveit, 2016). When developing an ASLT protocol that would be useful for predicting the lettuce shelf life, selected objective measurements that are highly correlated with subjective ratings will increase sensitivity.

An important factor to consider when developing an ASLT for lettuce is the influence of storage temperature on the cultivar response to key quality parameters and shelf life. When freshcut iceberg-type lettuce was evaluated to determine the degree of temperature stress on quality during storage at 5,10 , or $20^{\circ} \mathrm{C}$, the overall appearance rating decreased 2 -fold when stored at $10{ }^{\circ} \mathrm{C}$ and 6 -fold when stored at $20^{\circ} \mathrm{C}$ (Cantwell and Suslow, 2002). In-depth quality evaluations of individual lettuce accessions with different potential shelf lives at these temperatures have not been reported. Shelf life of some lettuce cultivars is more prone to decay, irrespective of the storage conditions (Hayes and Liu, 2008; Hayes et al., 2014; Kandel et al., 2020).

The objectives of this study were to develop an ASLT procedure that could be adopted by lettuce breeders: 1) by determining which quality traits most rapidly limit shelf life during storage at recommended temperatures and above recommended temperatures, and 2 ) by evaluating the decline in these key quality traits using three baseline lettuce accessions with long or short shelf lives.

\section{Materials and methods}

Test 1. Thirty-six Romaine lettuce heads [12 bags of three heads each $(n=36)]$ were purchased on arrival at a local grocery store in Gainesville, FL (25 July 2018), and immediately transported to the Postharvest Horticulture Laboratory at the University of Florida in Gainesville. California-grown lettuce was selected at the start of experiment because of the unavailability of Florida lettuce during the summer months. Experimental setup began immediately. Individual heads were randomly placed in breathable, high-density polyethylene bags [Narrow Profile Produce Bags $(14 \times 18$ inches $)$, model No. S-19156; Uline, Pleasant Prairie, WI] that maintained a high RH of $95 \%$ to $98 \%$ within each loosely sealed bag. Polymeric films have a low water vapor transmission rate (Lee and Chandra, 2018), favoring development of condensation when sealed. In preliminary tests, condensation was noted but was not considered significant. Lettuce heads were then stored at $5,10,15$, or $20^{\circ} \mathrm{C}$ to simulate varying levels of temperature stress. Initial measurements were noted as day 0 . Samples were evaluated after 2,4 , 6,8 , and $10 \mathrm{~d}$ of storage.

Test 2. In Test 1, storage at either 10 or $15^{\circ} \mathrm{C}$ segregated Romaine lettuce quality traits; therefore, lettuce was only stored at those two temperatures in Test 2. Two lettuce cultivars (Okeechobee and La Brillante) and one breeding line (60182) were found to have a range of shelf lives in preliminary experiments (C.E. Belisle, unpublished data) and were selected to develop an ASLT threshold. 'Okeechobee' (3 Stars Lettuce, Gonzales, CA) is a commercial Romaine cultivar extensively grown in south Florida with a 2 - to 3 -week shelf life at $5{ }^{\circ} \mathrm{C}$. Breeding line 60182 is a Romaine type from the University of Florida's lettuce breeding program with similar shelf life to 'Okeechobee' (C.E. Belisle, unpublished data). 'La Brillante' (USDAAgricultural Research Service, Salinas, CA) is an heirloom Batavia cultivar originally from France that was introduced to the United States in 1936 (Wehner, 2002); this cultivar is known for its short $(<14 \mathrm{~d})$ shelf life (Hayes and Liu, 2008). The three lettuce accessions ('Okeechobee', 60182, and 'La Brillante') were planted on 9 Oct. 2018 (winter harvest season) and 9 Mar. 2019 (spring harvest season) in a commercial field in Belle Glade, FL. The soil was primarily Histosols with $\approx 80 \%$ organic matter (Snyder, 2005). All production practices were conducted by the grower, who followed standard practices for this region. The lettuce heads $(\mathrm{n}=22$ heads per accession) were harvested on 7 Dec. 2018 and on 25 Apr. 2019 from 8:00 to 10:00 AM.

Immediately after harvest, heads were rinsed with well water to remove excess soil and immersion-hydrocooled for 20 to $30 \mathrm{~min}$ in chlorinated water $\left(100 \mathrm{mg} \cdot \mathrm{L}^{-1}\right)$ at $\mathrm{pH} 7$ and 0 to $5{ }^{\circ} \mathrm{C}$. Excess water was removed by shaking the heads, which were immediately placed into coolers (120 qt) that had a 3- to 6-inch layer of crushed ice on the bottom; a piece of 
waxed, corrugated fiberboard was placed on top of the ice to prevent freeze damage to the lettuce heads. After traveling $4 \mathrm{~h}$ to the Postharvest Horticulture Laboratory, lettuce was kept overnight at $1^{\circ} \mathrm{C}$. Setup and evaluations began the following day, which was designated as day 0 . Sample preparation was repeated as it was for Test 1; however, lettuce samples were stored for $10 \mathrm{~d}$ at 10 or $15^{\circ} \mathrm{C}$ for the Winter 2018 harvest and at $10^{\circ} \mathrm{C}$ for the Spring 2019 harvest to assess seasonal variations.

Quality PARAMETERs. The quality traits were selected from previous reports of lettuce quality (Agüero et al., 2008; Martín-Diana et al., 2006). Whole lettuce heads $(\mathrm{n}=3)$ were visually evaluated for "overall appearance" using a hedonic rating scale developed by Kader et al., (1973). Ratings were based on the visible leaves, which included outer leaves and distal ends of middle and inner leaves. The 9-point scale indicated the following: 1 point $=$ extremely poor, not useable; 3 points $=$ poor, excessive defects, not salable; 5 points $=$ fair, slightly to moderately objectionable defects, lower limit of salability; 7 points $=$ good, minor defects, not objectionable; and 9 points = excellent, essentially free from defects. Detailed definitions for each rating are shown in Table 1. For these tests, the lettuce was considered commercially marketable when the rating was above the predetermined threshold of 5 .

Weight loss percent was calculated by determining the proportion of loss for each head $(n=3)$ at each evaluation $(2,4,6,8$, and $10 \mathrm{~d})$ relative to its initial weight. Weight loss of each head was calculated on a fresh weight basis.

Color was measured immediately after removing lettuce from cold storage [three heads per accession and four leaves per head $(n=12)$ ]. The color was measured using a colorimeter (Chroma Meter CR-400; Konica Minolta, Tokyo, Japan) with Commission Internationale de l'Elcairage (CIE) $\mathrm{L}^{*} \mathrm{a} \mathrm{b}^{*}$ color space, D65 illuminant, and an $8-\mathrm{mm}$ aperture. One reading per leaf was performed on the abaxial side of leaf blades removed from the outer layer of lettuce heads. Color values were assessed as lightness* $\left[\mathrm{L}^{*}(0=\right.$ black, $100=$ white $)]$, chroma* value $\left(\mathrm{C}^{*}\right)$ (color purity: 0 = dull/low purity;

Table 1. Subjective overall appearance rating criteria for whole-head lettuce during storage.

\begin{tabular}{|c|c|c|}
\hline Score & Visual quality description $^{\mathrm{z}}$ & Detailed description $^{\mathrm{y}}$ \\
\hline 9 & $\begin{array}{l}\text { Excellent, essentially free } \\
\text { from defects }\end{array}$ & $\begin{array}{l}\text { Field fresh, turgid midribs and leaves, } \\
\text { bright color, no defects }\end{array}$ \\
\hline 7 & $\begin{array}{l}\text { Good, minor defects, } \\
\text { not objectionable }\end{array}$ & $\begin{array}{l}\text { Reasonably fresh, turgid midribs and } \\
\text { leaves, bright color } \\
\text { Appearance of minor defects: one to } \\
\text { three lesions (deterioration or yellowing) } \\
\text { each with a diameter }<0.5 \mathrm{~cm}\end{array}$ \\
\hline 5 & $\begin{array}{l}\text { Fair, slightly to moderately } \\
\text { objectionable defects, } \\
\text { lower limit of salability }\end{array}$ & $\begin{array}{l}\text { Loss of freshness, slight denting in midribs } \\
\text { and/or wilting of leaves, slight yellowing } \\
\text { and/or dull green color of leaves } \\
\text { Appearance of slight to moderate defects: } \\
\text { more than three lesions (deterioration or } \\
\text { yellowing) and/or lesions with a diameter } \\
>0.5 \mathrm{~cm}\end{array}$ \\
\hline 3 & $\begin{array}{l}\text { Poor, excessive defects, } \\
\text { not saleable }\end{array}$ & $\begin{array}{l}\text { Dull appearance, limp midribs and/or } \\
\text { wilted leaves, moderate yellowing and/ } \\
\text { or dull green color of leaves } \\
\text { Appearance of excessive defects: more than } \\
\text { three lesions (deterioration or yellowing) } \\
\text { and/or lesions with a diameter }>1 \mathrm{~cm}\end{array}$ \\
\hline 1 & $\begin{array}{l}\text { Extremely poor, not } \\
\text { useable }\end{array}$ & $\begin{array}{l}\text { Severe deterioration of tissue, limp midribs } \\
\text { and/or wilted leaves, severe yellowing of } \\
\text { leaves }\end{array}$ \\
\hline
\end{tabular}

${ }^{\mathrm{z}}$ Scale adapted from Kader et al. (1973).

${ }^{\mathrm{y}} 1 \mathrm{~cm}=0.3937$ inch

$60=$ bright $/$ high purity), and hue* angle $\left[\mathrm{h}^{*}\left(0^{\circ}=\mathrm{red}, 90^{\circ}=\right.\right.$ yellow, $180^{\circ}=$ green $)$.

Crispness of lettuce midribs was assessed by determining the deformation force (Newtons) at the bioyield point (the force at which irreversible damage to the tissue occurred) using a texture analyzer (model TA.HDPlus; Texture Technologies Corp, Hamilton, MA) with a $5-\mathrm{kg}$ load cell affixed to a single blade ( $3 \mathrm{~mm}$ wide, flat surface) driven at a crosshead speed of $100 \mathrm{~mm} \cdot \mathrm{min}^{-1}$. A midrib segment ( 3 inches) was excised from the center of each leaf, and excess leaf tissue was removed parallel to the midrib [three heads per accession and four leaves per head $(\mathrm{n}=12)$ ] (Supplemental Fig. 1). Each midrib was oriented perpendicular to the blade with the abaxial surface facing upward (Baur et al., 2005; Han et al., 2004; Toole et al., 2000).

Statistical analysis. The postharvest storage experiments (Tests 1 and 2) were conducted with three replicates (overall appearance and weight loss percent) or 12 replicates (color and crispness) per treatment using a completely randomized design. In Test 1 , a repeated measures analysis was performed for raw data using the PROC MIXED procedure in SAS software (version 9.4; SAS Institute, Cary, $\mathrm{NC)}$ to examine the increase or decrease in quality parameters during storage. An autoregressive $[\operatorname{AR}(1)]$ covariance model was used, with storage time $\times$ temperature as a random effect. In the analysis of variance (ANOVA), the factors, storage time, and temperature were considered fixed effects (Littell et al., 2006), and differences were computed using the $\mathrm{F}$ value in the ANOVA with a 5\% level of significance.

In Test 2, a similar analysis using repeated measures was conducted. The $\mathrm{AR}(1)$ covariance model was structured using replicates nested to season as a random effect, whereas accession, harvest season, storage time, and their interactions were considered fixed effects. Differences between accessions, harvest season, and storage time were determined as previously described $(P<0.05)$.

Simple linear correlations between overall appearance and individual quality parameters (weight loss, $\mathrm{L}^{*}, \mathrm{C}^{*}, \mathrm{~h}^{*}$, or bioyield point) were performed for Tests 1 and 2 to determine the statistical association between variables independent of accession, harvest season, or storage 
time. Linear regressions between overall appearance (the independent variable) and color, bioyield point, and weight loss (the dependent variables) were carried out for each storage temperature in Test 1 and for each, environment (temperature $\times$ harvest season) or accession in Test 2 . All correlation and regression analyses were performed using JMP Pro 15 software (SAS Institute) and differences were computed using Tukey's honestly significant difference test (Supplemental Table 1).

\section{Results and discussion}

In Test 1 , differences were found in overall appearance ratings $(P<0.0001)$ among lettuce heads due to storage temperature $\left(5,10,15\right.$, or $\left.20^{\circ} \mathrm{C}\right)$ (Fig. 1). Romaine lettuce at warmer temperatures $\left(15\right.$ or $\left.20^{\circ} \mathrm{C}\right)$ reached the marketability threshold rating of 5 by $4 \mathrm{~d}$, whereas lettuce stored at $10^{\circ} \mathrm{C}$ was marketable for $6 \mathrm{~d}$. Overall appearance of lettuce remained "excellent" (score of 9) during the entire $10 \mathrm{~d}$ of storage at $5^{\circ} \mathrm{C}$. Similar rates of overall quality decline were reported for whole Romaine lettuce heads at $5^{\circ} \mathrm{C}$ (Han et al., 2004) and $20^{\circ} \mathrm{C}$ (Samara and Konstantinos, 2009). As storage temperatures increased, respiration rate and subsequent metabolic processes increased, hastening senescence. For Romaine lettuce, the respiration rate increased from 2 -fold to 2.5-fold for each $5{ }^{\circ} \mathrm{C}$ increase in storage temperature $\left(5,10,15\right.$, or $\left.20^{\circ} \mathrm{C}\right)(\mathrm{Can}-$ twell and Suslow, 2002).

Romaine lettuce had little weight loss $(0 \%$ to $2 \%)$ throughout the $10 \mathrm{~d}$ storage period at 5,10 , or $15^{\circ} \mathrm{C}$;

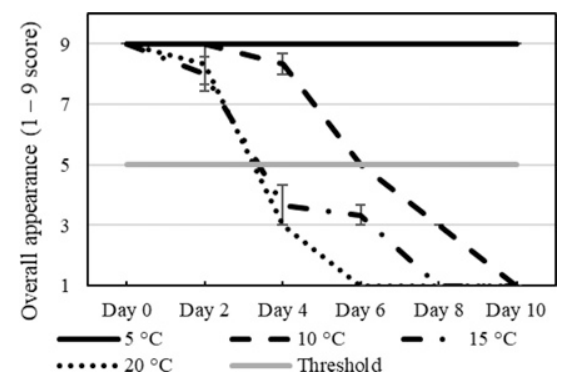

Fig. 1. Effect of storage temperature on visual ratings of overall appearance for Romaine lettuce from Test 1 during $10 \mathrm{~d}$ of storage at $5,10,15$, or $20{ }^{\circ} \mathrm{C}\left(41.0,50.0,59.0\right.$, or $\left.68.0{ }^{\circ} \mathrm{F}\right)$.

Hedonic scale where 1 = unusable, 3 = poor, 5 = fair, 7 = good, and $9=$ excellent. Gray line at rating 5 represents the marketability threshold. Bars represent the SE $(n=3)$. however, weight loss significantly increased by day 4 for lettuce stored at $20^{\circ} \mathrm{C}(P<0.0001)$, with $\approx 7 \%$ of the initial weight lost by day 10 (Fig. 2). Interestingly, at $20^{\circ} \mathrm{C}$, a significant increase in weight loss occurred between the final marketable day [day 2 $(0.44 \%)]$ and the first unmarketable day [day $4(2.5 \%)$ ]. Similar results were reported after $2 \mathrm{~d}$ at $20^{\circ} \mathrm{C}$ : two cultivars of whole head lettuce (unidentified type) stored in perforated plastic bags had significant weight loss (Suthumchai et al., 2006). Water loss is a primary sign of quality decline in lettuce, with symptoms of wilting, shriveling, and softening appearing; these occur with an estimated 3\% water loss (Paull, 1999) when stored at $\mathrm{RH}$ $<95 \%$ to $98 \%$ (Agüero et al., 2010). The occurrence of stresses during storage, such as light exposure, temperature $>2.2^{\circ} \mathrm{C}$, and $\mathrm{RH}<95$ to $98 \%$, accelerates senescence (Ben-Yehoshua, 1985). The loss of marketability at $20^{\circ} \mathrm{C}$ in this research may be partially caused by stress induced by the high storage temperature.

During storage at 5 or $10^{\circ} \mathrm{C}$, the $\mathrm{L}^{*}$ values were similar $(50.0-54.7)$ $\left[P>0.05\right.$ (Fig. 3A) ], $C^{*}$ values slightly declined (from 36.3 to 31.5 ) $\left[P=0.23\right.$ (Fig. 3B)], and $h^{*}$ angles slightly increased (from 117.6 to 120.0), where yellow hue $=90^{\circ}$ and green hue $=180^{\circ}[P<0.05$ (Fig. $3 \mathrm{C})$ ]. In a previous study, the $\mathrm{L}^{*}$ and $\mathrm{C}^{*}$ values did not significantly change for fresh-cut Romaine lettuce when stored at $5{ }^{\circ} \mathrm{C}$ for $14 \mathrm{~d}$ (Manolopoulou et al., 2010). Additionally, low-dose electron beam irradiation applied to prepackaged Romaine hearts before 21 $\mathrm{d}$ of storage at $4{ }^{\circ} \mathrm{C}$ resulted in no variation in $\mathrm{C}^{*}$ values, despite slight visual

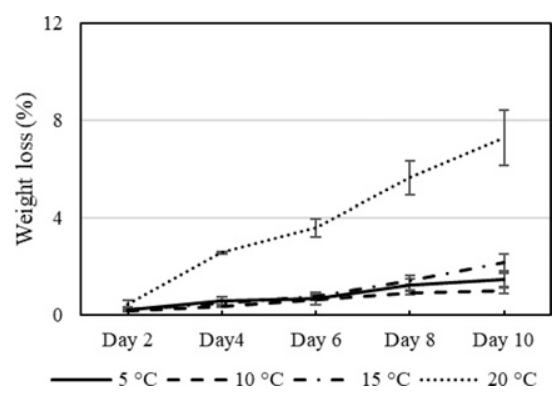

Fig. 2. Effect of storage temperature on weight loss percent for Romaine lettuce from Test 1 during $10 \mathrm{~d}$ of storage at $5,10,15$, or $20^{\circ} \mathrm{C}$ (41.0, $50.0,59.0$, or $68.0{ }^{\circ} \mathrm{F}$ ). Bars represent the SE $(\mathbf{n}=\mathbf{3})$.
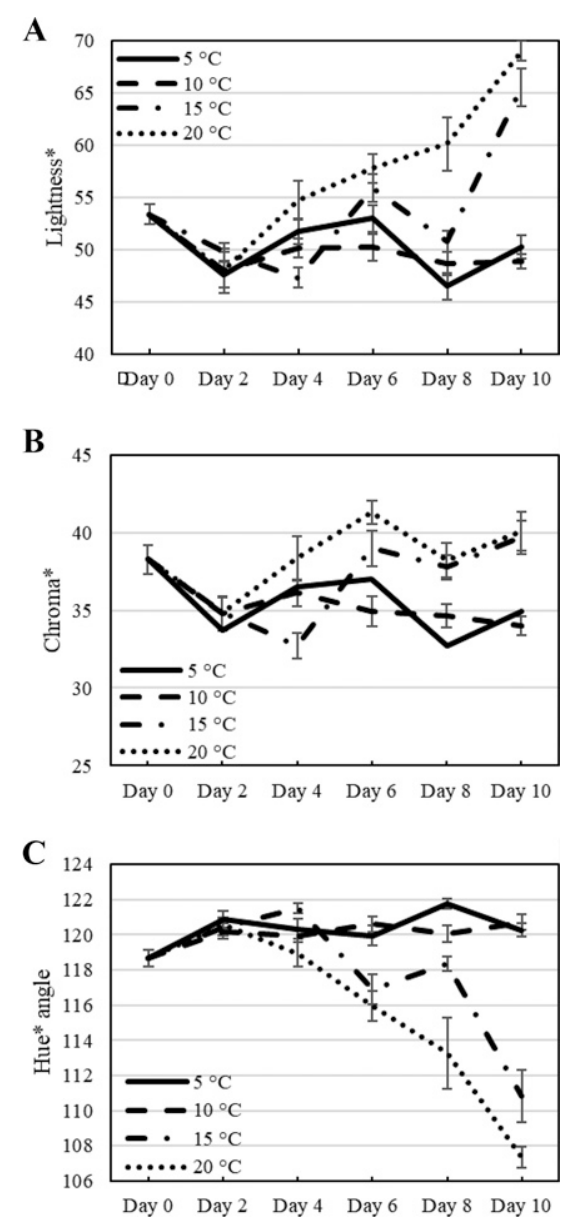

Fig. 3. Changes in abaxial leaf color values for Romaine lettuce from Test 1 for $10 \mathrm{~d}$ of storage at $5,10,15$, or $20{ }^{\circ} \mathrm{C}\left(41.0,50.0,59.0\right.$, or $\left.68.0{ }^{\circ} \mathrm{F}\right)$. Lightness* value $($ black $=0$; white $=$ $100)$, chroma* value (low $=0$; high $=$ $60)$, hue* angle ( $\mathrm{red}=0^{\circ}$; yellow $=$ $90^{\circ}$; green $\left.=180^{\circ}\right)$. Bars represent the SE $(\mathbf{n}=12)$.

changes in color (Han et al., 2004). Similar trends were observed during previous research for Romaine lettuce stored at 4 to $5^{\circ} \mathrm{C}$, whereby $\mathrm{h}^{*}$ increased over time (Han et al., 2004; Manolopoulou et al., 2010). In the current study, Romaine lettuce heads stored for $10 \mathrm{~d}$ at 5 or $10^{\circ} \mathrm{C}$ maintained acceptable overall color, which indicated that storage above $10^{\circ} \mathrm{C}$ is more discriminating of quality attributes related to shelf life.

When Romaine lettuce was stored at 15 or $20^{\circ} \mathrm{C}$, the $\mathrm{L}^{*}$ and $\mathrm{C}^{*}$ values significantly increased $\left(\mathrm{L}^{*}=50.1\right.$ to $68.5 ; \mathrm{C}^{*}=30.7$ to 36.3$)[P<$ 0.0001 (Fig. 3A and B)], whereas the $\mathrm{h}^{*}$ angle presented a noteworthy loss in green color (120.5 to 108.0) $[P<$ 0.0001 (Fig. $3 \mathrm{C}$ )]. At $15^{\circ} \mathrm{C}, \mathrm{L}^{*}$ 
increased from 54.0 to 63.0 from 8 to $10 \mathrm{~d}$; at $20^{\circ} \mathrm{C}, \mathrm{L}^{*}$ values constantly increased from day $2(50.1)$ to day 10 (68.5). Loss of chlorophyll, resulting in yellowing, is common at $20^{\circ} \mathrm{C}$, as previously reported (Suthumchai et al., 2006). In the current study, storage at $20^{\circ} \mathrm{C}$ led to yellowing and visible decay after $2 \mathrm{~d}$ of storage, whereas yellowing appeared before decay in lettuce stored at $15^{\circ} \mathrm{C}$. Storage at or above $20^{\circ} \mathrm{C}$ causes physiological changes, such as microbial decay, in fresh produce that are distinct from those occurring at lower, commonly used lettuce storage temperatures (Nunes and Emond, 2003). Therefore, storage at $20^{\circ} \mathrm{C}$ would not result in reliable indicators for ASLT.

The lettuce heads remained crisp during storage at 5 and $10^{\circ} \mathrm{C}$, as determined by the bioyield point (Newtons) $[P>0.05$ (Supplemental Table 2)]. Similar findings were reported for fresh-cut Romaine lettuce stored at $5^{\circ} \mathrm{C}$ for $8 \mathrm{~d}$ and at 0 or $5^{\circ} \mathrm{C}$ for $20 \mathrm{~d}$ (Artés et al., 1999; Manolopoulou et al., 2010). However, after $10 \mathrm{~d}$ at 15 or $20^{\circ} \mathrm{C}$, the bioyield point of the lettuce midribs was significantly $(P<$ 0.0001 ) lower, declining to 2.7 and $1.0 \mathrm{~N}$, respectively (Supplemental Table 3). The results indicated that storage temperature significantly affected the crispness of Romaine lettuce midribs; however, within each temperature, it was determined that midrib crispness was not a useful parameter for determining ASLT because of high variability between midrib samples from outer to inner leaves within a head. Accurate determination of the midrib bioyield point requires a precise and consistent measurement method; for instance, a larger sample size is highly recommended (Martín-Diana et al., 2006) to address the variability.

To determine which quality traits are associated with overall appearance, simple linear correlations were calculated for each quality attribute $[P<0.05$ (Supplemental Table 1)]. Overall appearance was negatively correlated with weight loss $(r=-0.79)$ and $L^{*}$ $(r=-0.64)$, and it was positively correlated with the $\mathrm{h}^{*}$ angle $(r=0.66), \mathrm{C}^{*}$ $(r=0.35)$, and crispness $(r=0.58)$. Because of their strong relationship with the visual deterioration of lettuce, weight loss, $\mathrm{L}^{*}$, and $\mathrm{h}^{*}$ were determined to be the most useful objective measurements for predicting shelf life.

Table 2. Regression analysis for the relationship between visual quality ratings $(x)$ and individual quality attributes $(y)$ in Test 1 of store-bought Romaine lettuce over $10 \mathrm{~d}$ of storage.

\begin{tabular}{|c|c|c|}
\hline Variable $(y)^{\mathrm{z}}$ & Equation & $\mathbf{P}$ \\
\hline Weight loss (\%) & $y=3.16-0.33 x$ & $<0.0001$ \\
\hline $5^{\circ} \mathrm{C}$ & $\mathrm{y}=0.69+0 \mathrm{x}$ & \\
\hline $10^{\circ} \mathrm{C}$ & $\mathrm{y}=1.16-0.11 \mathrm{x}$ & $<0.0001$ \\
\hline $15^{\circ} \mathrm{C}$ & $y=1.69-0.21 x$ & $<0.0001$ \\
\hline $20^{\circ} \mathrm{C}$ & $y=5.75-0.75 x$ & $<0.0001$ \\
\hline Lightness* $\left(\mathrm{L}^{*}\right)$ & $y=58.36-0.68 x$ & $<0.0001$ \\
\hline $5^{\circ} \mathrm{C}$ & $y=52.90+0 x$ & \\
\hline $10^{\circ} \mathrm{C}$ & $y=52.66-0.07 x$ & 0.6152 \\
\hline $15^{\circ} \mathrm{C}$ & $y=56.98-0.49 x$ & 0.0377 \\
\hline $20^{\circ} \mathrm{C}$ & $\mathrm{y}=62.70-1.39 x$ & $<0.0001$ \\
\hline Chroma* $\left(\mathrm{C}^{*}\right)$ & $\mathrm{y}=32.48+0.14 \mathrm{x}$ & 0.0071 \\
\hline $5^{\circ} \mathrm{C}$ & $y=33.51+0 x$ & \\
\hline $10^{\circ} \mathrm{C}$ & $\mathrm{y}=31.22+0.25 \mathrm{x}$ & 0.0093 \\
\hline $15^{\circ} \mathrm{C}$ & $\mathrm{y}=32.13+0.29 x$ & 0.0024 \\
\hline $20^{\circ} \mathrm{C}$ & $y=32.96+0.17 x$ & 0.2466 \\
\hline Hue* angle $\left(\mathrm{h}^{*}\right)$ & $y=115.73+0.41 x$ & $<0.0001$ \\
\hline $5^{\circ} \mathrm{C}$ & $\mathrm{y}=119.30+0 \mathrm{x}$ & \\
\hline $10^{\circ} \mathrm{C}$ & $\mathrm{y}=119.80+0.09 x$ & 0.0852 \\
\hline $15^{\circ} \mathrm{C}$ & $\mathrm{y}=115.83+0.44 \mathrm{x}$ & 0.0036 \\
\hline $20^{\circ} \mathrm{C}$ & $y=113.48+0.76 x$ & $<0.0001$ \\
\hline Crispness $(\mathrm{N})$ & $\mathrm{y}=2.79+0.15 \mathrm{x}$ & $<0.0001$ \\
\hline $5^{\circ} \mathrm{C}$ & $\mathrm{y}=3.97+0 \mathrm{x}$ & \\
\hline $10^{\circ} \mathrm{C}$ & $y=3.65+0.04 x$ & 0.4204 \\
\hline $15^{\circ} \mathrm{C}$ & $y=2.55+0.21 x$ & 0.0035 \\
\hline $20^{\circ} \mathrm{C}$ & $\mathrm{y}=2.32+0.26 \mathrm{x}$ & 0.0156 \\
\hline
\end{tabular}

Regression analysis was used to quantify the relationships between overall appearance (independent variable) and each quality attribute (dependent variables). For weight loss, if the overall appearance rating decreased by one rating unit, then weight loss was predicted to decrease by $0 \%, 0.11 \%$, $0.21 \%$, or $0.75 \%$ at $5,10,15$, or $20^{\circ} \mathrm{C}$, respectively $[P<0.0001$ (Table 2$)]$. The same trend occurred for $\mathrm{C}^{*}$ values: a visual rating decrease of one unit predicted $C^{*}$ increases of $0,0.25$, or 0.29 $\mathrm{C}^{*}$ at 5,10 , or $15^{\circ} \mathrm{C}$, respectively. For $\mathrm{L}^{*}, \mathrm{~h}^{*}$, and crispness, regression analyses revealed insignificant trends at lower temperatures $\left(5\right.$ or $\left.10^{\circ} \mathrm{C}\right)$ and significant trends at higher temperatures $\left(15\right.$ or $20^{\circ} \mathrm{C}$ ), with few exceptions. Therefore, storage at 5 or $10^{\circ} \mathrm{C}$ did not provide significant increases/ decreases in the slope of the regression equation; on the contrary, when the quality rating scores slowly increased/ decreased over time, they did not provide discriminatory power for objective measurements (individual quality attributes) useful for ASLT. However, the opposite was detected at higher temperatures of 15 and $20^{\circ} \mathrm{C}$, at which these changes in slopes occurred more drastically and quickly over time.

Initially, the most discriminating results were observed for Romaine lettuce stored at 10 or $15^{\circ} \mathrm{C}$ for weight loss and $\mathrm{C}^{*}$. At $15^{\circ} \mathrm{C}$, these were reflected in both overall appearance scores and objective quality attributes (weight loss, color, bioyield point). However, at $10^{\circ} \mathrm{C}$, quality loss was revealed in the overall appearance ratings and slightly in color values. Overall appearance ratings can be accurate and reliable, with good overall repeatability; however, a clear and detailed lexicon is needed to reduce bias from multiple evaluators (Simko and Hayes, 2018). Based on the lack of change in quality parameters during storage at 
$5^{\circ} \mathrm{C}$ and the excessive deterioration at $20^{\circ} \mathrm{C}$ in Test 1 , storage for Test 2 was conducted only at 10 or $15^{\circ} \mathrm{C}$ using two lettuce cultivars (Okeechobee, La Brillante) and one breeding line (60182).

In Test 2 , there were differences in overall appearance among the three accessions, independent of the harvest season and the storage temperature $(P<0.0001)$. 'Okeechobee' maintained at least "fair" overall appearance (score of 5) for most of the study [ $10 \mathrm{~d}$ at $10^{\circ} \mathrm{C}$ and $8 \mathrm{~d}$ at $15^{\circ} \mathrm{C}$ for the winter harvest, $8 \mathrm{~d}$ at $10^{\circ} \mathrm{C}$ for the spring harvest (Fig. 4A)]. The breeding line 60182 was almost identical to
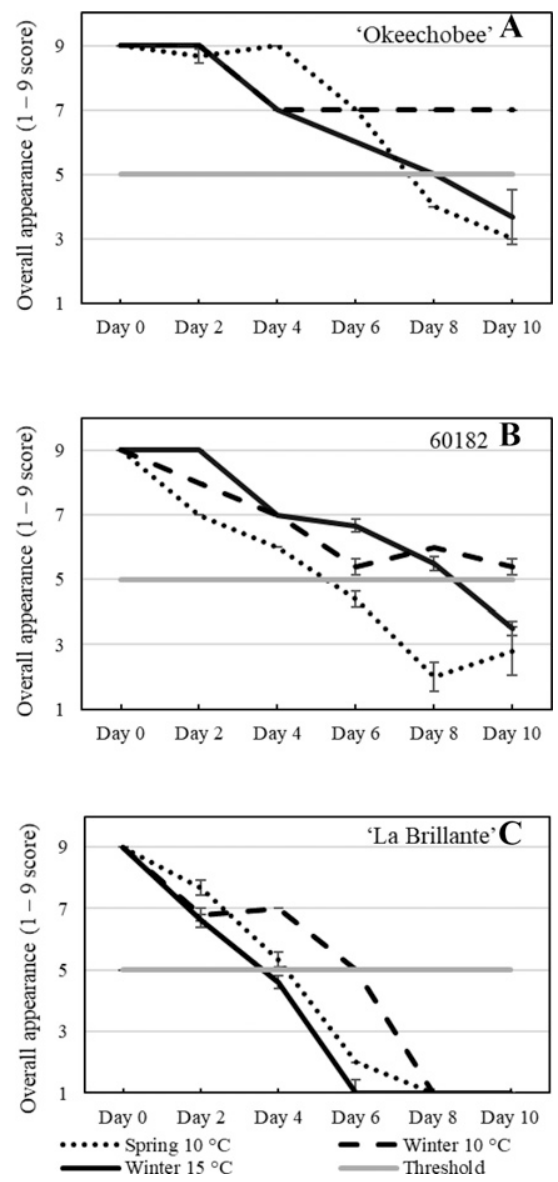

Fig. 4. Effect of storage temperature on visual ratings of overall appearance for 'Okeechobee' (A) and breeding line 60182 (B) Romaine lettuce, and 'La Brillante' (C) Batavia lettuce accessions from Test 2 harvested during Winter 2018 and Spring 2019 and evaluated during $10 \mathrm{~d}$ of storage at 10 or $15^{\circ} \mathrm{C}\left(50.0\right.$ or $\left.59.0{ }^{\circ} \mathrm{F}\right)$. Hedonic scale where 1 = unusable, 3 = poor, 5 = fair, 7 = good, and $9=$ excellent. Gray line at rating 5 represents the marketability threshold. Bars represent the SE $(n=3)$.
'Okeechobee' ["fair" appearance rating for $10 \mathrm{~d}$ at $10^{\circ} \mathrm{C}$ and $6 \mathrm{~d}$ at $15^{\circ} \mathrm{C}$ for the winter harvest, and for $8 \mathrm{~d}$ at $10^{\circ} \mathrm{C}$ for the spring harvest (Fig. 4B)]. Overall appearance in 'La Brillante', however, deteriorated quickly, reaching a score of 5 within $6 \mathrm{~d}$ at $10^{\circ} \mathrm{C}$ and within $4 \mathrm{~d}$ at $15^{\circ} \mathrm{C}$ in the winter harvest, and within $4 \mathrm{~d}$ at $10^{\circ} \mathrm{C}$ in the spring harvest (Fig. 4C). Lettuce from the spring harvest deteriorated more quickly when stored at $10^{\circ} \mathrm{C}$ than lettuce from the winter harvest. Lettuce deterioration rate has been reported to be variable because of different growing seasons and locations, indicating that the deterioration rate is influenced by environmental conditions (Clarkson et al., 2005; Hayes et al., 2014; Lee et al., 2017; Simko et al., 2014).

Weight loss was significantly different $(P<0.0001)$ among cultivars during storage and between the winter and spring harvests. Overall, 'Okeechobee' and 60182 had less weight loss $(<4 \%)$ than 'La Brillante' $(7.46 \%$ to $12.77 \%$ ) (Fig. 5). Weight loss was not significant $[P=0.68$ (Supplemental Table 4)] in 'Okeechobee' during storage, except at $10^{\circ} \mathrm{C}$ for the winter harvest when a gradual increase occurred $[P=0.04$ (Fig. 5A)]. Many factors contribute to weight loss during storage, including low $\mathrm{RH}(<95 \%)$ (Agüero et al., 2010) and the larger leaf cell size found in some lettuce types (Clarkson et al., 2005). Almost no weight loss $(P>0.05)$ was detected for 60182 during the first $8 \mathrm{~d}$ for all temperatures and harvests; however, on day 10 , the fresh weight losses were $2 \%$ and $4 \%$ at 10 and $15{ }^{\circ} \mathrm{C}$, respectively, for the winter harvest (Fig. 5B). Weight loss was significantly higher for 'La Brillante' compared with that of the other cultivars $[P<0.0001$ (Supplemental Table 4)], regardless of harvest or storage temperature (Fig. 5C). Photosynthesis and transpiration rates contributed to the variations in the water content of the two lettuce types and their storage environments. The variations between growing seasons were likely caused by a decline in stomatal conductance in older tissue from the winter harvest ( $59 \mathrm{~d}$ ) as compared with tissue from the spring harvest (47 d). Additionally, 'Okeechobee' and 60182 are adapted to Florida growing conditions, whereas 'La Brillante' is not adapted to the Florida or California environments, which was most likely
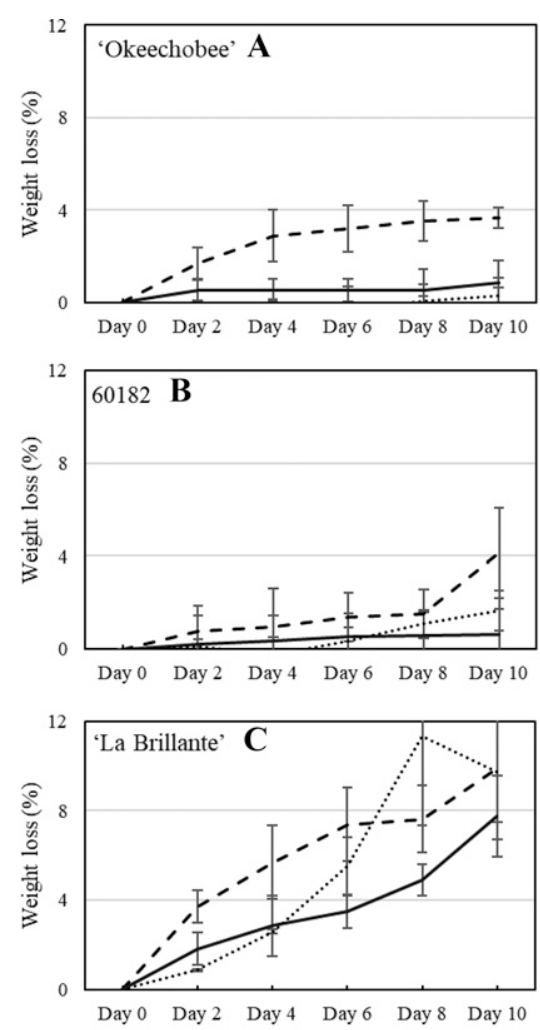

........ Winter $15^{\circ} \mathrm{C}-$ - Winter $^{\circ} 10^{\circ} \mathrm{C} \longrightarrow$ Spring $10^{\circ} \mathrm{C}$

Fig. 5. Effect of storage temperature on weight loss percent for 'Okeechobee' (A) and breeding line 60182 (B) Romaine lettuce, and ' $\mathrm{La}$ Brillante' (C) Batavia lettuce accessions from Test 2 harvested during Winter 2018 and Spring 2019 and evaluated during $10 \mathrm{~d}$ of storage at 10 or $15^{\circ} \mathrm{C}\left(50.0\right.$ or $\left.59.0{ }^{\circ} \mathrm{F}\right)$. Bars represent the $S E(n=3)$.

the reason for the rapid weight loss of 'La Brillante'.

Significant differences among accessions were found for $\mathrm{L}^{*}(P<$ $0.0001), \mathrm{C}^{*}(P<0.0001)$, and $\mathrm{h}^{*}$ $(P<0.0001)$ throughout storage, regardless of accession, harvest, or storage temperature (Fig. 6). The $\mathrm{L}^{*}$ values slightly increased in winter and spring lettuce stored at $10^{\circ} \mathrm{C}$ for all three accessions, whereas $\mathrm{L}^{*}$ values during winter at $15^{\circ} \mathrm{C}$ increased significantly after $6 \mathrm{~d}$ (Fig. 6A-C). The $\mathrm{C}^{*}$ values also increased slightly for the winter and spring harvests of 'Okeechobee' and 60182 during storage at $10^{\circ} \mathrm{C}$, whereas the $\mathrm{C}^{*}$ values of these two accessions stored at $15^{\circ} \mathrm{C}$ (winter harvest) increased dramatically after day 4 . The C* values for 'La Brillante' decreased slightly by day 10 for all storage temperatures (Fig. 6D-F). The $h^{*}$ angles decreased slightly for all 

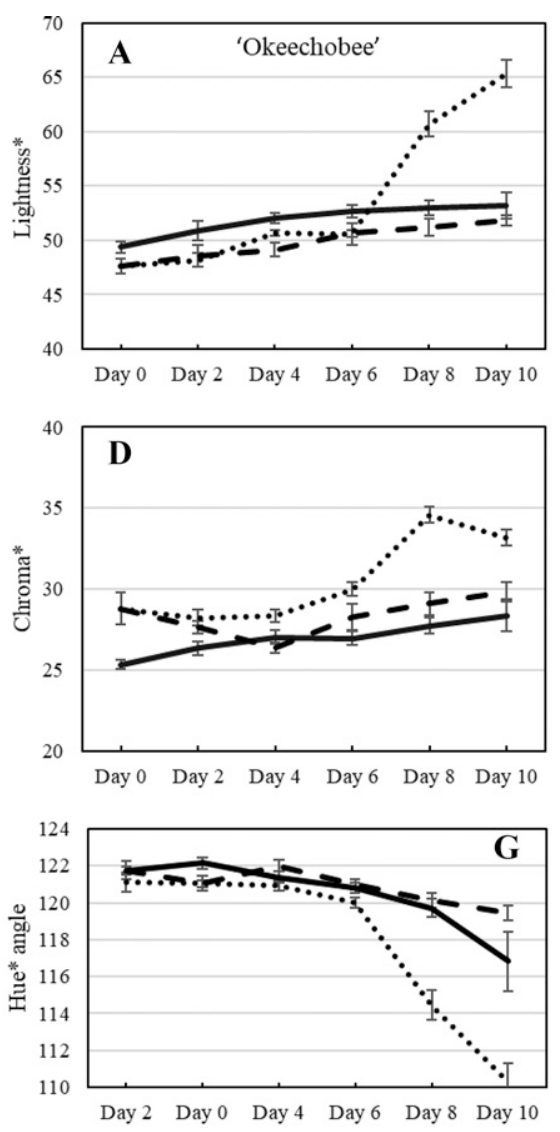

- Winter $10^{\circ} \mathrm{C} \ldots \ldots$ Winter $15^{\circ} \mathrm{C} \longrightarrow$ Spring $10^{\circ} \mathrm{C}$
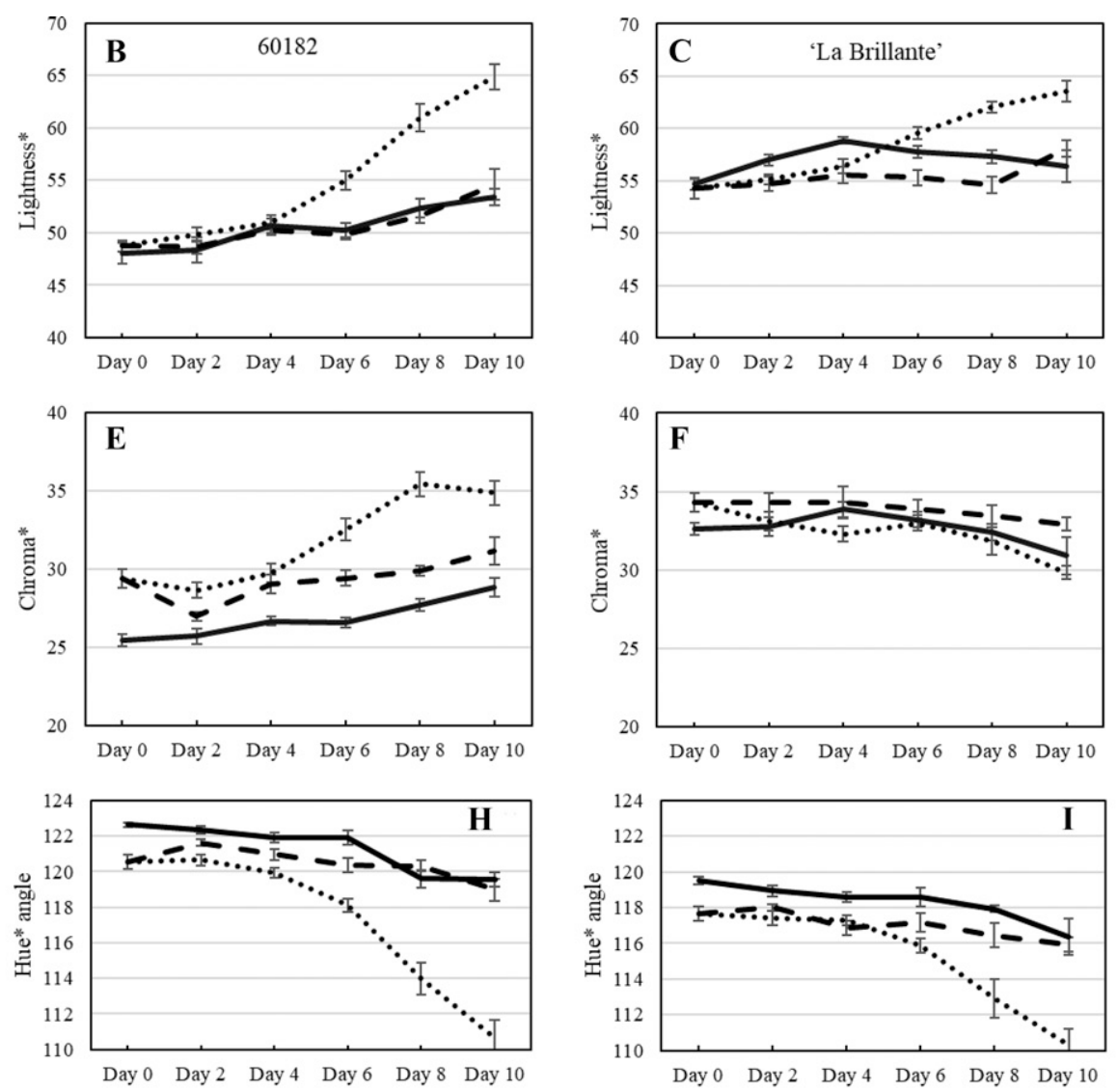

Fig. 6. Changes in abaxial leaf color values of lettuce leaves for 'Okeechobee' $(\mathrm{A}, \mathrm{D}, \mathrm{G})$ and breeding line 60182 (B, E, H) Romaine lettuce, and 'La Brillante' (C, F, I) Batavia lettuce accessions from Test 2 harvested during Winter 2018 and Spring 2019 and evaluated during $10 \mathrm{~d}$ of storage at 10 or $15^{\circ} \mathrm{C}\left(50.0\right.$ or $\left.59.0{ }^{\circ} \mathrm{F}\right)$. Lightness* value [ black $=0$; white $=100$ $(\mathrm{A}-\mathrm{C})]$, chroma* value $[$ low $=0$; high $=600(\mathrm{D}-\mathrm{F})]$, and hue* angle $\left[\right.$ red $=0^{\circ}$; yellow $=90^{\circ} ;$ green $\left.=180^{\circ}(\mathrm{G}-\mathrm{I})\right] . \mathrm{Bars}$ represent the SE $(n=12)$.

accessions harvested in winter and spring and stored at $10^{\circ} \mathrm{C}$, and they decreased significantly for winter harvest when stored at $15^{\circ} \mathrm{C}$ (Fig. $\left.6 \mathrm{G}-\mathrm{I}\right)$. These results indicate that color differences were most distinct for $10 \mathrm{~d}$ of storage at $15^{\circ} \mathrm{C}$. However, $10^{\circ} \mathrm{C}$ might be useful to discriminate subtle differences in $\mathrm{L}^{*}, \mathrm{C}^{*}$, and $\mathrm{h}^{*}$ among cultivars. 'Okeechobee' and 60182 are dark green Romaine lettuces, whereas 'La Brillante' is a yellow-green Batavia type, as shown by its higher $\mathrm{h}^{*}$ angle (lighter leaf color). Therefore, researchers must consider the diversity of pigmentation among lettuce accessions (Lee et al., 2005) when discriminating among them.

Midrib crispness, measured by the bioyield point, remained constant for the initial and final values of the three accessions, irrespective of harvest or storage temperature $[P=0.77$ (Supplemental Table 5)]. It is noteworthy that, as in Test 1 , crispness varied sufficiently during storage to make this variable invalid for ASLT. Midrib crispness fluctuated during storage for 'Okeechobee' (3.79-9.62 $\mathrm{N}), 60182(2.29-6.28 \mathrm{~N})$, and ' $\mathrm{La}$ Brillante' (1.06-4.34 N). Similar fluctuations for this attribute were reported for Romaine (Manolopoulou et al., 2010) and iceberg lettuce types (Toole et al., 2000). The differences among lettuce accessions identified in the present test were likely due to the differences in midrib size and density between the Batavia and Romaine types. Therefore, the values were not indicative of shelf life at any point during storage, regardless of harvest or storage temperature.

Simple linear correlations were calculated between overall appearance and individual quality attributes $[P<$ 0.001 (Supplemental Table 1)]. Overall appearance strongly correlated with weight loss $(r=-0.81), \mathrm{L}^{*}(r=$ $-0.84)$, and $\mathrm{h}^{*}(r=0.81)$, and it moderately correlated with $\mathrm{C}^{*}(r=$ $-0.66)$ and crispness $(r=0.48)$. The similarities in correlations between Tests 1 and 2 validated weight loss, $\mathrm{L}^{*}$, and $\mathrm{h}^{*}$ as the quality traits that most rapidly determine the shelf life of the different lettuce accessions tested when using 10 or $15^{\circ} \mathrm{C}$ as storage temperatures. Regression coefficients for $L^{*}$ and $h^{*}$ were similar for heads stored at $10^{\circ} \mathrm{C}$, regardless of harvest (winter or spring). For $\mathrm{C}^{*}$, weight loss, and bioyield point, the coefficients were more differentiated for both storage temperatures and both harvests (Table 3 ). These findings indicate that variability due to harvest and storage temperature must be considered when designing tests to predict shelf life using ASLT.

The regression analysis to discriminate among cultivars and the breeding line for each variable (weight loss, $\mathrm{L}^{*}$, $\mathrm{C}^{*}, \mathrm{~h}^{*}$, and crispness) determined that coefficients for 'Okeechobee' and 
Table 3. Regression analysis for the relationship between visual quality ratings $(x)$ and quality attributes ( $y$ ) in Test 2 of Romaine ('Okeechobee' and breeding line 60182) and Batavia ('La Brillante') lettuce over $10 \mathrm{~d}$ of storage.

\begin{tabular}{|c|c|c|}
\hline Variable $(y)^{\mathbf{z}}$ & Equation & $P$ \\
\hline Weight loss (\%) & $y=6.26-0.66 x$ & $<0.0001$ \\
\hline Winter $15^{\circ} \mathrm{C}$ & $y=6.14-0.76 x$ & $<0.0001$ \\
\hline Winter $10^{\circ} \mathrm{C}$ & $y=8.20-0.81 x$ & $<0.0001$ \\
\hline Spring $10^{\circ} \mathrm{C}$ & $y=5.38-0.57 x$ & $<0.0001$ \\
\hline Lightness* $\left(\mathrm{L}^{*}\right)$ & $\mathrm{y}=61.30-1.30 \mathrm{x}$ & $<0.0001$ \\
\hline Winter $15^{\circ} \mathrm{C}$ & $y=65.43-1.79 x$ & $<0.0001$ \\
\hline Winter $10^{\circ} \mathrm{C}$ & $y=57.42-0.82 x$ & $<0.0001$ \\
\hline Spring $10^{\circ} \mathrm{C}$ & $\mathrm{y}=58.03-0.88 \mathrm{x}$ & $<0.0001$ \\
\hline Chroma* $\left(\mathrm{C}^{*}\right)$ & $y=33.31-0.52 x$ & $<0.0001$ \\
\hline Winter $15^{\circ} \mathrm{C}$ & $y=33.85-0.43 x$ & $<0.0001$ \\
\hline Winter $10^{\circ} \mathrm{C}$ & $\mathrm{y}=33.49-0.47 x$ & 0.0003 \\
\hline Spring $10^{\circ} \mathrm{C}$ & $\mathrm{y}=32.34-0.60 \mathrm{x}$ & $<0.0001$ \\
\hline Hue* $^{*}$ angle $\left(\mathrm{h}^{*}\right)$ & $y=114.20+0.78 x$ & $<0.0001$ \\
\hline Winter $15^{\circ} \mathrm{C}$ & $y=110.92+1.10 x$ & $<0.0001$ \\
\hline Winter $10^{\circ} \mathrm{C}$ & $y=116.37+0.48 x$ & $<0.0001$ \\
\hline Spring $10^{\circ} \mathrm{C}$ & $\mathrm{y}=117.42+0.49 x$ & $<0.0001$ \\
\hline Crispness $(\mathrm{N})$ & $y=3.28+0.26 x$ & $<0.0001$ \\
\hline Winter $15^{\circ} \mathrm{C}$ & $y=2.90+0.36 x$ & 0.0001 \\
\hline Winter $10^{\circ} \mathrm{C}$ & $y=2.32+0.38 x$ & 0.0008 \\
\hline Spring $10^{\circ} \mathrm{C}$ & $\mathrm{y}=4.33+0.11 \mathrm{x}$ & 0.1662 \\
\hline
\end{tabular}

${ }^{\mathrm{z}}$ Variables include all lettuces ('Okeechobee', 60182, and 'La Brillante'); $\mathrm{L}^{*}$ (black $=0$; white $=100$ ), $\mathrm{C}^{*}$ $($ low $=0 ;$ high $=60), \mathrm{h}^{*}\left(\mathrm{red}=0^{\circ} ;\right.$ yellow $=90^{\circ}$; green $\left.=180^{\circ}\right) ;\left(1.8 \times{ }^{\circ} \mathrm{C}\right)+32={ }^{\circ} \mathrm{F} ; 1 \mathrm{~N}=0.2248 \mathrm{lbf}$.

Table 4. Regression analysis for the relationship between visual quality ratings $(\mathrm{x})$ and quality attributes ( $\mathrm{y})$ in Test 2 of Romaine ('Okeechobee' and breeding line 60182) and Batavia ('La Brillante') lettuce over $10 \mathrm{~d}$ of storage.

\begin{tabular}{|c|c|c|}
\hline Variable $(\mathrm{y})^{\mathrm{z}}$ & Equation & $P$ \\
\hline Weight loss (\%) & $y=6.26-0.66 x$ & $<0.0001$ \\
\hline 'Okeechobee' & $y=2.72-0.22 x$ & 0.0005 \\
\hline 60182 & $y=3.18-0.26 x$ & 0.0012 \\
\hline 'La Brillante' & $y=7.88-0.82 x$ & $<0.0001$ \\
\hline Lightness* (L*) & $\mathrm{y}=61.30-1.30 \mathrm{x}$ & $<0.0001$ \\
\hline 'Okeechobee' & $y=64.49-1.79 x$ & $<0.0001$ \\
\hline 60182 & $y=63.56-1.83 x$ & $<0.0001$ \\
\hline 'La Brillante' & $y=59.56-0.59 x$ & $<0.0001$ \\
\hline Chroma* $\left(\mathrm{C}^{*}\right)$ & $y=33.31-0.52 x$ & $<0.0001$ \\
\hline 'Okeechobee' & $y=32.68-0.59 x$ & $<0.0001$ \\
\hline 60182 & $y=35.15-0.93 x$ & $<0.0001$ \\
\hline 'La Brillante' & $y=32.35+0.13 x$ & 0.0283 \\
\hline Hue* angle $\left(h^{*}\right)$ & $y=114.20+0.78 x$ & $<0.0001$ \\
\hline 'Okeechobee' & $y=112.06+1.11 x$ & $<0.0001$ \\
\hline 60182 & $\mathrm{y}=112.45+1.13 \mathrm{x}$ & $<0.0001$ \\
\hline 'La Brillante' & $y=115.39+0.38 x$ & $<0.0001$ \\
\hline Crispness $(\mathrm{N})$ & $y=3.28+0.26 x$ & $<0.0001$ \\
\hline 'Okeechobee' & $y=6.84+0.04 x$ & 0.6622 \\
\hline 60182 & $\mathrm{y}=5.44-0.10 \mathrm{x}$ & 0.2273 \\
\hline 'La Brillante' & $y=2.47+0.01 x$ & 0.8500 \\
\hline
\end{tabular}

${ }^{2}$ Variables include storage at $10^{\circ} \mathrm{C}$ for winter and spring harvests and $15^{\circ} \mathrm{C}$ for winter harvest; $\mathrm{L}^{*}$ (black $=0$; white $=100), \mathrm{C}^{*}($ low $=0$; high $=60), \mathrm{h}^{*}\left(\right.$ red $=0^{\circ}$; yellow $=90^{\circ}$; green $\left.=180^{\circ}\right) ;\left(1.8 \times{ }^{\circ} \mathrm{C}\right)+32={ }^{\circ} \mathrm{F} ; \mathrm{l}$ $\mathrm{N}=0.2248 \mathrm{lbf}$.
60182 were similar, whereas coefficients for 'La Brillante' were more distinct (Table 4). Overall, these findings validate that both genetic differences among the three accessions (Hayes et al., 2014; Simko et al., 2014) and ambient temperatures during the growing seasons contribute to shelf life (Clarkson et al., 2005; Lee et al., 2017).

Considering the overall appearance rating when using the regression equations, the percentage of weight loss was predicted to be between $0.88 \%$ and $1.04 \%$ at the marketability threshold rating of 5 ("fair"). Furthermore, $\mathrm{L}^{*}$ was predicted to decline by 7.16 to 7.32 units and $h^{*}$ angle was predicted to increase by 4.44 to $4.52^{\circ}$. These ranges of weight loss, $\mathrm{L}^{*}$, and $\mathrm{h}^{*}$ angle are specific to the accessions evaluated. Therefore, a general reference is presented for determining lettuce shelf life potential based on quality attributes of Romaine accessions during storage at either 10 or $15^{\circ} \mathrm{C}$ (Table 5 ). Additionally, quality changes during storage at 4 to $5^{\circ} \mathrm{C}$ can be extrapolated to shelf life using a conversion from Cantwell and Suslow (2002), who determined that a 2 -fold to 2.5 -fold increase in respiration occurs with each $5{ }^{\circ} \mathrm{C}$ increase in storage temperature, which is directly proportional to the deterioration rate. Therefore, using these respiration rates, a cultivar with a shelf life of 9 to $12 \mathrm{~d}$ at $10^{\circ} \mathrm{C}$ or of 3 to $8 \mathrm{~d}$ at $15^{\circ} \mathrm{C}$ would be predicted to maintain quality for more than $14 \mathrm{~d}$ during storage at $5{ }^{\circ} \mathrm{C}$ (Table 5 ).

In conclusion, head weight loss, $\mathrm{L}^{*}$, and $\mathrm{h}^{*}$ angle were identified as the key quality parameters that will permit breeders to use ASLT to more rapidly predict shelf life of lettuce accessions. $\mathrm{L}^{*}$ and $h^{*}$ angle were most accurate when measured on outer leaf tissue during storage at 10 or $15^{\circ} \mathrm{C}$, and they were effective indices across harvests. Color measurement comparisons should only be performed within a lettuce type to avoid bias based on lettuce pigmentation. For storage at $15^{\circ} \mathrm{C}$, accessions with "poor" and "good" shelf lives can be determined within less than $3 \mathrm{~d}$, and rapid evaluations of a large number of lettuce accessions are recommended. Storage at $10^{\circ} \mathrm{C}$ separates "poor" accessions within less than $9 \mathrm{~d}$, and is better suited for finer discrimination of variations in shelf life. Finally, to best assess shelf life of lettuce accessions in field trials and storage tests, it is recommended 
Table 5. Reference for determining whole-head Romaine lettuce shelf life during storage at 10 or $15^{\circ} \mathrm{C}$.

\begin{tabular}{lccr}
\hline & \multicolumn{3}{c}{ Shelf life potential } \\
\cline { 2 - 4 } Attribute $^{\mathrm{z}}$ & Good & Intermediate $^{\mathrm{z}}$ & Poor \\
\hline Weight loss $(\%)$ & $0-2$ & $2-4$ & $>4$ \\
Lightness* $\left(\mathrm{L}^{*}\right)$ & $<55$ & $50-55$ & $>55$ \\
Hue* angle $\left(\mathrm{h}^{*}\right)$ & $>120$ & $118-120$ & $<120$ \\
Predicted shelf life $\left(5^{\circ} \mathrm{C}\right)$ & $>21 \mathrm{~d}$ & $14-21 \mathrm{~d}$ & $<\mathrm{l} 4 \mathrm{~d}$ \\
Predicted shelf life $\left(10^{\circ} \mathrm{C}\right)$ & $11-12 \mathrm{~d}$ & $9-10 \mathrm{~d}$ & $<9 \mathrm{~d}$ \\
Predicted shelf life $\left(15^{\circ} \mathrm{C}\right)$ & $4-8 \mathrm{~d}$ & $3-6 \mathrm{~d}$ & $<3 \mathrm{~d}$ \\
\hline
\end{tabular}

${ }^{\mathrm{z}}$ Intermediate shelf-life quality is the point at which researcher discretion is necessary and subjective evaluations are beneficial. $L^{*}($ black $=0$; white $=100), h^{*}\left(\right.$ red $=0^{\circ}$; yellow $=90^{\circ}$; green $\left.=180^{\circ}\right)$. Predicted shelf-life values were calculated using respiration rates presented by Cantwell and Suslow $(2002) ;\left(1.8 \times{ }^{\circ} \mathrm{C}\right)+32={ }^{\circ} \mathrm{F}$.

to include cultivars with well-known "poor" and "acceptable" shelf lives as baseline reference points.

\section{Literature cited}

Achour, M. 2006. A new method to assess the quality degradation of food products during storage. J. Food Eng. 75:560-564, doi: https://doi.org/10.1016/j.jfoodeng. 2005.04.056.

Agüero, M.V., M.V. Barg, A. Yommi, A. Camelo, and S.I. Roura. 2008. Postharvest changes in water status and chlorophyll content of lettuce (Lactuca sativa L.) and their relationship with overall visual quality. J. Food Sci. 73:S47-S55, doi: https://doi. org/10.1111/j.1750-3841.2007.00604.x.

Agüero, M.V., A.G. Ponce, M.R. Moreira, and S.I. Roura. 2010. Lettuce quality loss under conditions that favor the wilting phenomenon. Postharvest Biol. Technol. 59:124-131, doi: https://doi.org/ 10.1016/j.postharvbio.2010.08.018.

Ansorena, M.R., M.G. Goñi, M.V. Aguëro, S.I. Roura, and K.C. Di Scala. 2009. Application of the general stability index method to assess the quality of butter lettuce during postharvest storage using a multi-quality indices analysis. J. Food Eng. 92:317-323, doi: https://doi.org/ 10.1016/j.jfoodeng.2008.11.016.

Artés, F., J.A. Martínez, and J.G. Mann. 1999. Quality changes in minimally processed 'Romaine' lettuce as affected by several treatments, p. 115-118. In: M. Hagg, R. Ahvenainen, A.M. Evers, and K. Tiilikkala (eds.). Agri-food quality II. Quality management of fruit and vegetables. Roy. Soc. Chem. Spec. Publ. 229, doi: https://doi. org/10.1533/9781845698140.4.115.

Baur, S., R. Klaiber, H. Wei, W.P. Hammes, and R. Carle. 2005. Effect of temperature and chlorination of pre-washing water on shelf-life and physiological properties of ready to use iceberg lettuce. Innov. Food Sci. Emerg. Technol. 6:171-
182, doi: https://doi.org/10.1016/j.ifset. 2005.02.002.

Ben-Yehoshua, S. 1985. Individual sealpackaging of fruit and vegetables in plastic film - A new postharvest technique. HortScience 20:32-37.

Bolin, H.R., A.E. Stafford, A.D. King, Jr., and C.C. Huxsoll. 1977. Factors affecting the storage stability of shredded lettuce. J. Food Sci. 42:1319-1321, doi: https:// doi.org/10.1111/j.1365-2621.1977.tbl 4487.x.

Cantwell, M.I. and T.V. Suslow. 2002. Postharvest handling systems: Fresh-cut fruits and vegetables, p. 445-463. In: A.A. Kader (ed.). Postharvest technology of horticultural crops. Univ. California, Agr. Natural Resources Publ. 3311.

Clarkson, G.J.J., S.D. Rothwell, and G. Taylor. 2005. End of day harvest extends shelf life. HortScience 40:1431-1435, doi: https://doi.org/10.21273/HORT SCI.40.5.1431.

Han, J., C.L. Gomes-Feitosa, E. CastellPerez, R.G. Moreira, and P.F. Silva. 2004. Quality of packaged romaine lettuce hearts exposed to low-dose electron beam irradiation. Lebensm. Wiss. Technol. 37:705-715, doi: https://doi.org/ 10.1016/j.lwt.2004.02.007.

Hayes, R.J. and Y.B. Liu. 2008. Genetic variation for shelf-life of salad-cut lettuce in modified-atmosphere environments. J. Amer. Soc. Hort. Sci. 133:228-233, doi: https://doi.org/10.21273/JASHS.133. 2.228 .

Hayes, R.J., C.H. Galeano, Y. Luo, R. Antonise, and I. Simko. 2014. Inheritance of decay of fresh-cut lettuce in a recombinant inbred line population from 'Salinas 88' $\times$ 'La Brillante'. J. Amer. Soc. Hort. Sci. 139:388-398, doi: https://doi.org/ 10.21273/JASHS.139.4.388.

Kader, A.A. 2002. Postharvest biology and technology: An overview, p. 39-48. In: A.A. Kader (ed.). Postharvest technology of horticultural crops. Univ. California, Agr. Natural Resources Publ. 3311.

Kader, A.A., W.J. Lipton, and L.L. Morris. 1973. Systems for scoring quality of harvested lettuce. HortScience 8:408-409.

Kandel, J.S., H. Peng, R.J. Hayes, B. Mou, and I. Simko. 2020. Genome-wide association mapping reveals loci for shelf-life and developmental rate of lettuce. Theor. Appl. Genet. 133:1947-1966, doi: https://doi. org/10.1007/s00122-020-03568-2.

Labuza, T.P. and M.K. Schmidl. 1985. Accelerated shelf-life testing of foods. Food Technol. 39(9):57-64.

Lee, J.S. and D. Chandra. 2018. Effects of different packaging materials and methods on the physical, biochemical and sensory qualities of lettuce. J. Food Sci. Technol. 55:1685-1694, doi: https:// doi.org/10.1007/s13197-018-3081-6.

Lee, J.S., J.W. Choi, D.S. Chung, C.I. Lim, T.C. Seo, G.L. Do, and C. Chun. 2005. Effects of lettuce (Lactuca sativa L.) cultivars and cultivation methods on growth, quality, and shelf-life. Kor. J. Hortic. Sci. Technol. 23:12-18. (in Korean, English abstr.).

Lee, J.S., U.K. Nath, G. Goswami, and I.S. Nou. 2017. Assessment of different growing conditions for enhanced postharvest quality and shelf-life of leaf lettuce (Lactuca sativa L.). Agron. Res. (Tartu) 15:1944-1955.

Littell, R.C., G.A. Milliken, W.W. Stroup, R.D. Wolfinger, and S. Oliver. 2006. SAS for mixed models. 2nd ed. SAS Inst., Cary, NC.

Manolopoulou, H., G.R. Lambrinos, E. Chatzis, G. Xanthopoulos, and E. Aravantinos. 2010. Effect of temperature and modified atmosphere packaging on storage quality of fresh-cut Romaine lettuce. J. Food Qual. 33:317-336, doi: https://doi.org/ 10.1111/j.1745-4557.2010.00321.x.

Martín-Diana, A.B., D. Rico, J. Frias, G.T.M. Henehan, J. Mulcahy, J.M. Barat, and C. Barry-Ryan. 2006. Effect of calcium lactate and heat-shock on texture in fresh-cut lettuce during storage. J. Food Eng. 77:1069-1077, doi: https://doi. org/10.1016/j.jfoodeng.2005.08.037.

Nunes, M.C. and J.P. Emond. 2003. Storage temperature, p. 209-288. In: J.A. Bartz, J.K. Brecht, and J. Weichmann (eds.). Postharvest physiology and pathology of vegetables. M. Dekker, New York, NY.

Paull, R.E. 1999. Effect of temperature and relative humidity on fresh commodity quality. Postharvest Biol. Technol. 15:263277, doi: https://doi.org/10.1016/S0 925-5214(98)00090-8. 
Saltveit, M. 2016. Lettuce, p. 386-389. In: K.C. Gross, C.Y. Wang, and M. Saltveit (eds.). The commercial storage of fruits, vegetables, and florist and nursery stocks. U.S. Dept. Agr., Agr. Res. Serv., Agr. Hdbk. 66.

Samara, A. and K.P. Konstantinos. 2009. Effect of treating lettuce surfaces with acidulants on the behaviour of Listeria monocytogenes during storage at 5 and $20^{\circ} \mathrm{C}$ and subsequent exposure to simulated gastric fluid. Intl. J. Food Microbiol. 129:1-7, doi: https://doi.org/10.1016/ j.ijfoodmicro.2008.10.023.

Simko, I., R.J. Hayes, C.T. Bull, B. Mou, Y. Luo, M.A. Trent, A.J. Atallah, E.J. Ryder, and R.G. Sideman. 2014. Characterization and performance of 16 new inbred lines of lettuce. HortScience 49:679-687, doi: https://doi.org/10.21273/HORTSCI. 49.5.679.

Simko, I. and R.J. Hayes. 2018. Accuracy, reliability, and timing of visual evaluations of decay in fresh-cut lettuce. PLoS One 13(4):e0194635, doi: https://doi.org/ 10.1371/journal.pone.0194635.

Snyder, G.H. 2005. Everglades agricultural area soil subsidence and land use projections. Annu. Proc. Soil Crop Sci. Soc. Florida 64:44-51.

Suthumchai, W., T. Matsui, K. Kawada, and Y. Kosugi. 2006. Changes in acid invertase activity and sugar contents in lettuce during storage at ambient temperature. Asian J. Plant Sci. 5:304-310.

Toole, G.A., M.L. Parker, A.C. Smith, and K.W. Waldron. 2000. Mechanical properties of lettuce. J. Mater. Sci. 35: 3553-3559.

Torres, C.A., L.A. Romero, and R.I. Diaz. 2015. Quality and sensory attributes of apple and quince leathers made without preservatives and with enhanced antioxidant activity. Food Sci. Technol. 62:996-
1003, doi: https://doi.org/10.1016/j. lwt.2015.01.056.

U.S. Department of Agriculture. 2019. Food availability (per capita) data system: Vegetable (fresh). 21 May 2020. < https:// www.ers.usda.gov/data-products/foodavailability-per-capita-data-system $/>$.

U.S. Department of Agriculture. 2020. Statistics by subject: National statistics for lettuce. 21 May 2020. <https://www. nass.usda.gov/Statistics_by_Subject $>$.

Wang, S., J. Tang, T. Sun, E.J. Mitcham, T. Koral, and S.L. Birla. 2006. Considerations in design of commercial radio frequency treatments for postharvest pest control in in-shell walnuts. J. Food Eng. 77:304-312, doi: https://doi.org/10. 1016/j.jfoodeng.2005.06.037.

Wehner, T.C. 2002. Vegetable cultivar descriptions for North America list 26. HortScience 37:15-78. 
Supplemental Table 1. Correlation coefficients for the relationship between overall appearance ratings and individual quality attributes of lettuce accessions during storage at $5,10,15$, or $20^{\circ} \mathrm{C}$ (Test 1 ) or 10 or $15^{\circ} \mathrm{C}($ Test 2$) .^{\mathrm{z}}$

\begin{tabular}{|c|c|c|c|c|c|}
\hline \multirow[b]{2}{*}{ Variable 1} & \multirow[b]{2}{*}{ Variable $2^{y}$} & \multicolumn{2}{|c|}{ Test 1} & \multicolumn{2}{|c|}{ Test 2} \\
\hline & & Correlation & $P$ & Correlation & $P$ \\
\hline \multirow[t]{4}{*}{ Overall appearance } & Lightness* (L*) & -0.64 & $<0.0001$ & -0.84 & $<0.0001$ \\
\hline & Hue* $^{*}$ angle $\left(h^{*}\right)$ & 0.66 & $<0.0001$ & 0.81 & $<0.0001$ \\
\hline & Weight loss (\%) & -0.79 & $<0.0001$ & -0.81 & $<0.0001$ \\
\hline & Crispness $(\mathrm{N})$ & 0.58 & $<0.0001$ & 0.48 & $<0.0001$ \\
\hline
\end{tabular}

${ }^{\mathrm{z}}\left(1.8 \times{ }^{\circ} \mathrm{C}\right)+32={ }^{\circ} \mathrm{F}$.

${ }^{y}$ Lightness* value $($ black $=0$; white $=100)$, chroma* value $($ low $=0$; high $=60)$, hue* angle $\left(\right.$ red $=0^{\circ} ;$ yellow $=90^{\circ}$; green $\left.=180^{\circ}\right) ; 1 \mathrm{~N}=0.2248$ lbf.

Supplemental Table 2. Effect of storage temperature on midrib crispness for Romaine lettuce from Test 1 during storage at $5,10,15$, or $20{ }^{\circ} \mathrm{C}(95 \%$ to $98 \%$ relative humidity).

\begin{tabular}{|c|c|c|c|c|c|c|}
\hline \multirow[b]{2}{*}{$\operatorname{Temp}\left({ }^{\circ} \mathbf{C}\right)^{\mathrm{z}}$} & \multicolumn{6}{|c|}{ Storage time $(\mathrm{d})$} \\
\hline & \multicolumn{6}{|c|}{ Midrib crispness $[\text { mean } \pm \operatorname{SE}(\mathrm{N})]^{\mathrm{y}}$} \\
\hline 5 & $4.4 \pm 0.47 \mathrm{~A}^{\mathrm{x}}$ & $3.9 \pm 0.50 \mathrm{~A}$ & $4.1 \pm 0.43 \mathrm{~A}$ & $2.8 \pm 0.34 \mathrm{~A}$ & $3.7 \pm 0.45 \mathrm{~A}$ & $4.1 \pm 0.30 \mathrm{~A}$ \\
\hline 10 & $4.4 \pm 0.47 \mathrm{~A}$ & $3.7 \pm 0.22 \mathrm{~A}$ & $3.5 \pm 0.22 \mathrm{~A}$ & $4 \pm 0.21 \mathrm{~A}$ & $2.8 \pm 0.50 \mathrm{~A}$ & $3.3 \pm 0.39 \mathrm{~A}$ \\
\hline 15 & $4.4 \pm 0.47 \mathrm{~A}$ & $3.7 \pm 0.31 \mathrm{AB}$ & $2.9 \pm 0.32 \mathrm{AB}$ & $3.5 \pm 0.35 \mathrm{AB}$ & $1.5 \pm 0.65 \mathrm{~B}$ & $2.7 \pm 0.42 \mathrm{AB}$ \\
\hline
\end{tabular}

$\bar{z}\left(1.8 \times{ }^{\circ} \mathrm{C}\right)+32={ }^{\circ} \mathrm{F}$.

${ }^{y}$ Crispness measured by determining the deformation force at the bioyield point (the peak at which irreversible damage to the tissue occurred). $1 \mathrm{~N}=0.2248 \mathrm{lbf}$.

${ }^{\mathrm{x}}$ Different letters within a row indicate a significant difference during storage time. Tukey's honestly significant difference at $P<0.05(\mathrm{n}=12)$.

Supplemental Table 3. Probability values for the analysis of variance in Test 1 for a subjective rating (visual) and objective measurements to determine Romaine lettuce shelf-life.

\begin{tabular}{|c|c|c|c|c|c|c|}
\hline Source & $\begin{array}{c}\text { Overall } \\
\text { appearance }\end{array}$ & Wt loss (\%) & Lightness* $\left(\mathrm{L}^{*}\right)^{\mathrm{z}}$ & Chroma* $\left(C^{*}\right)^{\mathbf{z}}$ & Hue* angle $\left(h^{*}\right)^{z}$ & Crispness $(\mathrm{N})^{\mathrm{y}}$ \\
\hline Time (d) & $<0.0001$ & $<0.0001$ & $<0.0001$ & $<0.0001$ & $<0.0001$ & $<0.0001$ \\
\hline 2 & 0.0109 & 0.9839 & 0.4784 & 0.1732 & 0.8022 & 0.6281 \\
\hline 4 & $<0.0001$ & 0.0162 & 0.3176 & 0.3683 & 0.5090 & 0.4215 \\
\hline 6 & $<0.0001$ & 0.0008 & $<0.0001$ & 0.0404 & $<0.0001$ & 0.2349 \\
\hline Temperature $\left({ }^{\circ} \mathrm{C}\right)^{\mathrm{x}}$ & $<0.0001$ & 0.0009 & $<0.0001$ & 0.2769 & $<0.0001$ & 0.0657 \\
\hline 5 & 1.0000 & 0.1748 & 0.2104 & 0.0005 & 0.0696 & 0.4225 \\
\hline 10 & $<0.0001$ & 0.6292 & 0.2771 & 0.0004 & 0.0749 & 0.4223 \\
\hline 15 & $<0.0001$ & 0.0095 & $<0.0001$ & 0.0016 & $<0.0001$ & $<0.0001$ \\
\hline
\end{tabular}

${ }^{\mathrm{Z}} \mathrm{L}^{*}($ black $=0$; white $=100), \mathrm{C}^{*}($ low $=0 ;$ high $=60), \mathrm{h}^{*}\left(\right.$ red $=0^{\circ} ;$ yellow $=90^{\circ} ;$ green $\left.=180^{\circ}\right)$.

${ }^{\mathrm{y}}$ Crispness measured by determining the deformation force at the biovield point, the peak at which irreversible damage to the tissue occurred. $1 \mathrm{~N}=0.2248 \mathrm{lbf}$.

${ }^{\mathrm{x}}\left(1.8 \times{ }^{\circ} \mathrm{C}\right)+32={ }^{\circ} \mathrm{F}$. 
Supplemental Table 4. Probability values for the analysis of variance in Test 2 for a subjective rating (visual) and objective measurements (rest of traits) to determine Romaine ('Okeechobee' and breeding line 60182) and Batavia ('La Brillante') lettuce shelf-life.

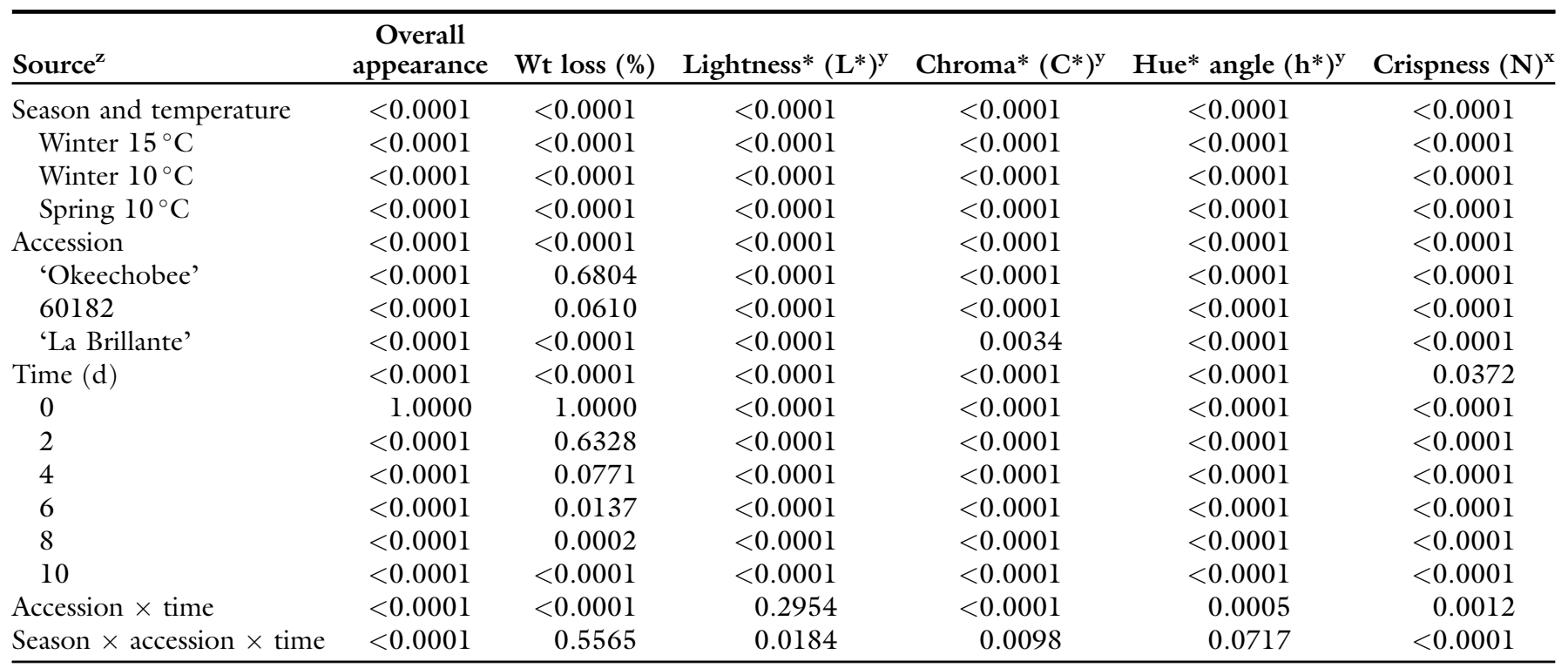

$\mathrm{z}^{\mathrm{z}}\left(1.8 \times \mathrm{x}{ }^{\circ} \mathrm{C}\right)+32={ }^{\circ} \mathrm{F}$.

${ }^{y} L^{*}($ black $=0 ;$ white $=100), C^{*}($ low $=0 ;$ high $=60), h^{*}\left(\right.$ red $=0^{\circ}$; yellow $=90^{\circ} ;$ green $\left.=180^{\circ}\right)$.

${ }^{\mathrm{x}}$ Crispness measured by determining the deformation force at the bioyield point (the peak at which irreversible damage to the tissue occurred). $1 \mathrm{~N}=0.2248 \mathrm{lbf}$.

Supplemental Table 5. Effect of storage temperature on midrib crispness for 'Okeechobee' (Romaine), the breeding line 60182 (Romaine), and 'La Brillante' (Batavia) lettuce accessions from Test 2 harvested in winter and spring seasons and evaluated during $10 \mathrm{~d}$ of storage at 10 or $15{ }^{\circ} \mathrm{C}(95 \%$ to $98 \%$ relative humidity).

\begin{tabular}{|c|c|c|c|c|c|c|c|}
\hline \multirow{3}{*}{$\begin{array}{l}\text { Tissue } \\
\text { indices }^{z}\end{array}$} & & \multicolumn{6}{|c|}{ Storage time $(\mathrm{d})$} \\
\hline & & $\mathbf{0}$ & 2 & 4 & 6 & 8 & 10 \\
\hline & & \multicolumn{6}{|c|}{ Mid-rib crispness $[\text { mean } \pm \operatorname{SE}(\mathrm{N})]^{\mathrm{y}}$} \\
\hline \multicolumn{8}{|c|}{ 'Okeechobee' } \\
\hline $15^{\circ} \mathrm{C}$ & Winter 2018 & $6.91 \pm 0.53 \mathrm{~A}^{\mathrm{x}}$ & $7.38 \pm 0.16 \mathrm{~A}$ & $9.62 \pm 0.90 \mathrm{~A}$ & $7.11 \pm 1.48 \mathrm{~A}$ & $6.44 \pm 1.36 \mathrm{~A}$ & $6.85 \pm 1.05 \mathrm{~A}$ \\
\hline $10^{\circ} \mathrm{C}$ & Winter 2018 & $6.91 \pm 0.53 \mathrm{~A}$ & $3.79 \pm 0.51 \mathrm{~B}$ & $6.01 \pm 0.88 \mathrm{AB}$ & $7.69 \pm 0.77 \mathrm{~A}$ & $8.57 \pm 0.77 \mathrm{~A}$ & $7.96 \pm 0.86 \mathrm{~A}$ \\
\hline $15^{\circ} \mathrm{C}$ & Winter 2018 & $3.98 \pm 0.29 \mathrm{~A}$ & $3.06 \pm 0.78 \mathrm{~A}$ & $4.65 \pm 0.35 \mathrm{~A}$ & $4.52 \pm 0.22 \mathrm{~A}$ & $6.28 \pm 1.41 \mathrm{~A}$ & $3.73 \pm 0.86 \mathrm{~A}$ \\
\hline $10^{\circ} \mathrm{C}$ & Winter 2018 & $3.98 \pm 0.29 \mathrm{~B}$ & $7.83 \pm 0.61 \mathrm{~A}$ & $4.73 \pm 0.29 \mathrm{~B}$ & $4.71 \pm 0.21 \mathrm{~B}$ & $4.48 \pm 0.47 \mathrm{~B}$ & $4.81 \pm 0.55 \mathrm{~B}$ \\
\hline $10^{\circ} \mathrm{C}$ & Spring 2019 & $3.7 \pm 0.22 \mathrm{AB}$ & $4.71 \pm 0.24 \mathrm{~A}$ & $2.29 \pm 0.73 \mathrm{~B}$ & $4.83 \pm 0.34 \mathrm{~A}$ & $5 \pm 0.36 \mathrm{~A}$ & $4.22 \pm 0.40 \mathrm{~A}$ \\
\hline \multicolumn{8}{|c|}{ 'La Brillante' } \\
\hline $15^{\circ} \mathrm{C}$ & Winter 2018 & $1.67 \pm 0.36 \mathrm{~B}$ & $3.97 \pm 0.73 \mathrm{~A}$ & $2.67 \pm 0.37 \mathrm{AB}$ & $1.06 \pm 0.24 \mathrm{~B}$ & $1.17 \pm 0.22 \mathrm{~B}$ & $1.06 \pm 0.29 \mathrm{~B}$ \\
\hline $10^{\circ} \mathrm{C}$ & Winter 2018 & $1.67 \pm 0.36 \mathrm{~A}$ & $1.61 \pm 0.53 \mathrm{~A}$ & $1.77 \pm 0.40 \mathrm{~A}$ & $1.35 \pm 0.27 \mathrm{~A}$ & $2.3 \pm 0.46 \mathrm{~A}$ & $1.26 \pm 0.38 \mathrm{~A}$ \\
\hline
\end{tabular}




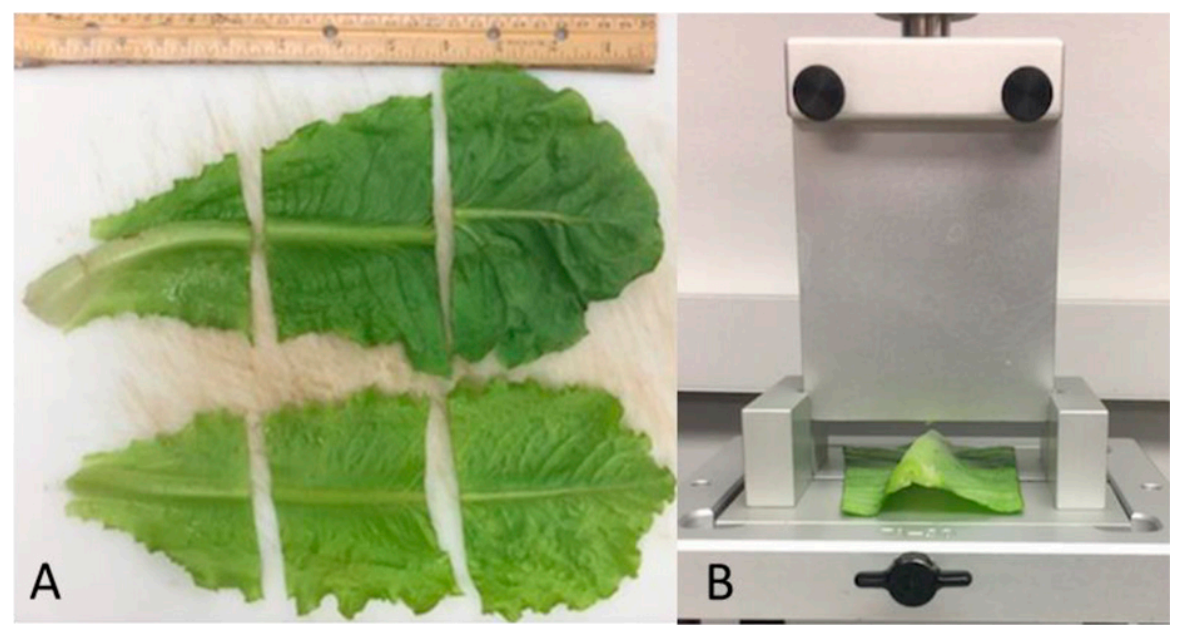

Supplemental Fig. 1. Setup to measure the rupture force of the lettuce leaf midrib. (A) Excision of the center 3-inch (7.62 $\mathrm{cm}$ ) midrib section. (B) Single, $3-\mathrm{mm}$ blade positioned $<5 \mathrm{~mm}$ above the center of the midrib. $1 \mathrm{~mm}=0.0394 \mathrm{inch}$. 